\title{
ULTRA HIGH DEFINITION
}

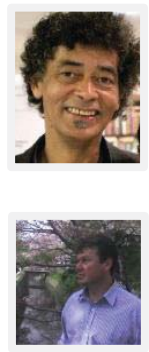

\section{Moderator: Almir Almas}

Professor and Researcher on the ECA/ PUC/ SET Graduate Audiovisual Means and Processes Program

8K Super Ultra High Definition, 4K Ultra High Definition 4K and live transmission

Speaker: Guido Lemos De Sousa Filho Founder, Professor and Researcher - Digital Video Applications Laboratory (Lavid) at the Federal University of Paraíba (UFPB)

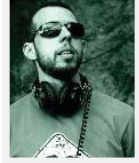

4K Ultra High Definition, DCP, state of the art and the paths to codec/standardizations

Speaker: Thiago Afonso De André

Coordenador de Produção Audiovisual e Tecnologia do Cinema (PPGMPA/USP)

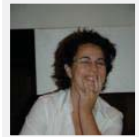

\section{Pixel race}

Speaker: Jane De Almeida - Professor / Mackenzie

Presbyterian University

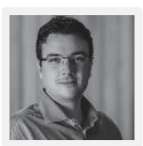

Case Study - UltraHD 4K and HDR - Technology, Esthetics and Production

Speaker: Paulo Barcellos

Managing Director of Post Production / O2Filmes

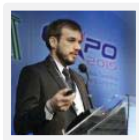

Olimpíadas em 8K: Medidas, Soluções, Tecnologia e Experiência.

Speaker: Christian Fragoas Fernandez Rodrigues

Engenheiro de projetos de telecomunicações da divisão de transmissao, pesquisa e desenvolvimento / Rede Globo

Do Ultra HDTV 4K ao Super Ultra HDTV 8K

Speaker: Raphael Varandas

Cinematographer (former DIT) 


\title{
ULTRA HIGH DEFINITION
}

\author{
Moderator: Almir Almas
}

Professor and Researcher on the ECA/ PUC/ SET Graduate Audiovisual Means and Processes Program

Research, state of the art and an approach to case studies in Super Ultra High Definition (8K) and Ultra High Definition (4K); workflow, technologies and the market.

- 8K Super Ultra High Definition, 4K Ultra High Definition 4K and live transmission

Speaker: Guido Lemos De Sousa Filho

Founder, Professor and Researcher - Digital Video Applications Laboratory (Lavid) at the Federal

University of Paraíba (UFPB)

- 4K Ultra High Definition, DCP, state of the art and the paths to

\section{codec/standardizations}

Speaker: Thiago Afonso De André

Audiovisual and Cinema Technology Production Coordinator (PPGMPA/USP)

Deals with workflows and the reality of the Brazilian market when dealing with high resolution; the mismatch between the technological possibilities, the wishes of promoters and producers and, in exchange, budgets, requirements and technical difficulties

- Pixel race

Speaker: Jane De Almeida

Professor / Mackenzie Presbyterian University

Higher resolution in moving pictures means augmenting the entire computing, processing and filing process. Every year, picture technology companies produce new equipment for sale, promising to increase the resolution like the increase in immersion capability and the realism of the pictures. Will the pixel race produce a final and stable resolution? The presentation will raise the problems with the issues regarding $8 \mathrm{k}$ pictures, based on research during the transmission of the 2014 FIFA World Cup Finals 2014

- Case Study - UltraHD 4K and HDR - Technology, Esthetics and Production Speaker: Paulo Barcellos Managing Director of Post Production / O2Filmes

O2Filmes approaches the issue from the point of view of production and the technical/esthetic discussion about the use of this technology; what is the way forward and the state of the art, the use of HDR color space and examples of the producer's cases.

- Olimpíadas em 8K: Medidas, Soluções, Tecnologia e Experiência. Speaker: Christian Fragoas Fernandez Rodrigues

Engenheiro de projetos de telecomunicações da divisão de transmissao, pesquisa e desenvolvimento / Rede Globo 
Compartilhar informações da experiência de captura, tratamento e transmissão de evento esportivo das Olimpíadas em 8K, em experiência realizada pela STRL-NHK/Japão e Rede Globo/Brasil, no Rio de Janeiro, em 2016.

- Do Ultra HDTV 4K ao Super Ultra HDTV 8K Speaker: Raphael Varandas Cinematographer (former DIT)
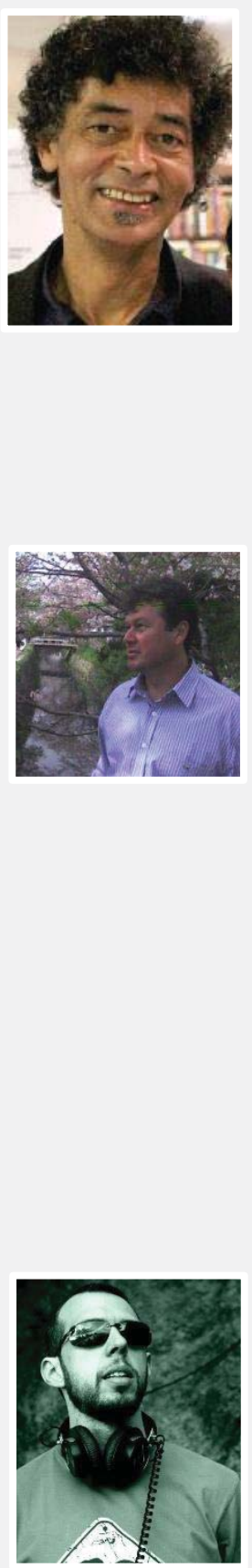

\section{ALMIR ALMAS}

Professor and Researcher on the ECA/ PUC/ SET Graduate Audiovisual Means and Processes Program - USP/ ECA/ SET

He holds a Doctorate and a Master's in Communication and Semiotics from the Pontifical Catholic University of São Paulo (PUC-SP). Professor and researcher on the Graduate Audiovisual Means and Processes Program, and in the Department of Cinema, Radio and Television of the School of Communications and Arts of the University of São Paulo, and researches digital television, interactivity, video, cinema, electronic arts and Japanese culture. Filmmaker and video artist, he is working on expanded cinema, VJing/live-image, video art, interventions in media and Japanese poetry. Author of the book "Televisão digital terrestre: sistemas, padrões e modelos", (free translation, Terrestrial digital television: systems, standards and models) published by Alameda Editorial, São Paulo, (2012). Member of the Editorial Committee of the Board of Directors of the Brazilian Society of Television Engineering (SET), since 2010.

\section{GUIDO LEMOS DE SOUSA FILHO}

Superintendência Fórum SBTVD / Fundador, Professor e Pesquisador do Lavid da UFPB He holds a Bachelor's Degree in Computer Science from the Federal University of Paraíba (1988), a Master's (1991) and a Doctorate (1997) in Informatics from the Pontifical Catholic University of Rio de Janeiro. He is currently head professor at the Federal University da Paraíba, a director of the Informatics Center $(\mathrm{Cl})$ and is doing research at the Digital Video Applications Laboratory (LAVID). He was involved in developing the Ginga middleware, published as ITU-T and ITU-R recommendations and adopted as the standard for the Brazilian Digital Television System, as well as for the systems of several other countries of Latin America and Africa. He works on research, development and innovation in the field of Multimedia Systems, involved primarily in the following topics: digital television, digital cinema, distributed multimedia applications, video distribution networks and distributed artistic performances. Worthy of note among the results of this research are the development of a system for storing, transmitting and displaying 3-D 4K videos, known as Fogo Player; the development of a support platform for holding distributed dance, theater and music spectacles, called Arthron and the development of video servers for live, on-demand transmission, known as DLive and DVod, used by the Digital Video Network of RNP and on the IPTV service of USP-SP. He is also a member of the Deliberative Council of the Forum on the Brazilian Digital Television System.

\section{THIAGO AFONSO DE ANDRÉ}

Audiovisual and Cinema Technology Production Coordinator - University of São Paulo (USP)

Reading for his Doctorate in Audiovisual Media and Processes at the University of São Paulo. He has an undergraduate degree in Molecular Sciences from the University of São Paulo (2002), a graduate degree on the Superior Audiovisual Course from the University of São Paulo (2010) and a Master's in Applied Mathematics from the University of São Paulo (2007). He is currently Audiovisual and Cinema Technology Production Coordinator University of São Paulo. 


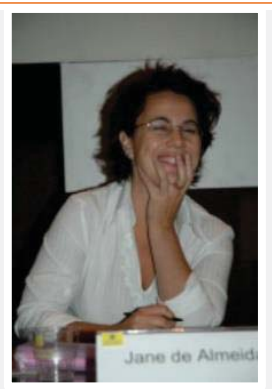

\section{JANE DE ALMEIDA}

Professor - Mackenzie Presbyterian University

ane de Almeida works in the arts, film and new media fields. She taught at the Visual Arts Department at UCSD (2008), and currently is a faculty member of Mackenzie University in São Paulo, Brazil.In 2008 she organized the first projection of 4k films in Brazil for cultural purposes at FILE (Electronic Language International Festival) and in 2009 organized, along with others, the first transcontinental transmission of $4 \mathrm{k}$ films in Latin America among three points: São Paulo (Mackenzie University), San Diego (UCSD) and Tokyo (DMC, Keio University). In 2010 she organized and directed the first 4K/3D movie about football exhibited during the World Cup 2010 in Johannesburg at the Casa Brasil. It is a part of the $2014 \mathrm{k}$ project that aims to stream in 4k 3D to movie theaters around the world the games of the 2014 World Cup (www.2014k.org). The presentation in South Africa was supported by FINEP (Research and Projects Financing). In 2011 she coordinated the project and directed the film StereoEssays (www.estereoensaios.com.br), supported by the RNP Agency (www.rnp.br). The project is part of the Working Group (GT) for the development of remote super-high definition visualization systems. The $4 \mathrm{k} / 3 \mathrm{D}$ film was presented at Cinegrid in Rio de Janeiro and Cinegrid 2011 in San Diego. It was exhibited in the Sesc Mostra de Artes (Art Exhibition) along with other 3D movies and as filminstallation in the exhibition Tecnofagias at the Tomie Ohtake Institute of Contemporary Art (http://www.mostradeartedigital.com.br/2012/artistas/jane-de-almeida.html).She has organized several books and has written articles about cinema, new digital technology and contemporary art.

Current research interests: Stereoscopy / high definition cinema: new ways to see (http://4k3d.wordpress.com/sinopse/english/)

Cinematic Arts: science as a cinema narrative

Cinema in grid: a new configuration of the telecommunication system www.estereoensaios.com.br

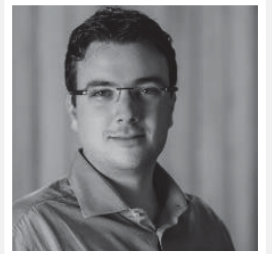

\section{PAULO BARCELLOS}

Managing Director of Post Production - O2Films

I believe that technology is the answer to most of the challenges we face in this field. So much can be done with present technology that makes it easy to get lost. Photography showed me the perspective, technology brought me the tools and my passion for filmmaking provides me the motivation to work in this exciting and challenging area.

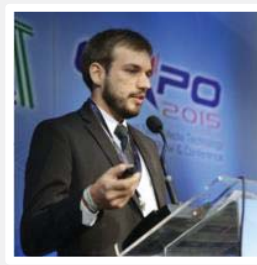

\section{CHRISTIAN FRAGOAS FERNANDEZ RODRIGUES}

Telecommunications projects engineer at the transmission, research and development division - Rede Globo

Brazilian, 26 years of age. His education background includes a Master's in Electronic Engineering from the State University of Rio de Janeiro (incomplete); an Undergraduate Degree in Electrical Engineering with the emphasis on Telecommunications, State University of Rio de Janeiro (2015) and an Undergraduate Degree in Systems Analysis and Development from the City College (2011). His professional background includes: Rede Globo (September-2015 to the present) as a telecommunications projects engineer at the transmission, research and development division. His activities include: Extending digital coverage in the State of Minas Gerais, Projects/Regularization of Microwave Links and Transmission testing for developing new technologies (UHDTV 4k/8k). Also at Rede Globo (September-2013 to August-2015) he was an Intern in the projects and installations area, engaging in: Development/enhancement of scripts involving the installation of microwave links (air space violation and channel interference studies); Regularization of microwave links; studying/designing Digital TV network coverage; assisting the engineers in partnership projects for developing new digital television technologies. He also worked at Brasil Telecom in the period from April 2012 to August 2013 as an Intern in the Release Management area, having been involved with: Maintenance of test and certification environment; maintenance of code version control systems; and the development auxiliary systems for the software quality area. He is also conversant in English.

\section{RAPHAEL VARANDAS}

Cinematographer (former DIT) 
Cinematographer (former DIT). He is an artist, and his works have been exhibited at the Fringe Biennale held at the São Paulo Pinacoteca and the Museum of Contemporary Art (MAC) at USP, among other museums in Brazil and abroad. He has works that belong to the collections of major contemporary art collectors, including Cossac Naiff and Marton. $\mathrm{He}$ is a founding partner of DCINE Cinematografia Digital, a company at the forefront of digital cinematography in São Paulo. He has been filming in RAW 4K+ since 2008. In Brazil, he was one of the first to have in his camera kit the RED One, Epic M and Weapon Helium 8K cameras. 